\title{
MEASUREMENTS OF GROUND-LEVEL OZONE IN CZECH MOUNTAIN FORESTS: WHAT WE HAVE LEARNT FROM USING DIFFUSIVE SAMPLERS
}

\author{
IVA HŮNOVÁ $1,2, *$ \\ ${ }^{1}$ Czech Hydrometeorological Institute, Prague, Czech Republic \\ 2 Institute for Environmental Studies, Charles University, Prague, Czech Republic \\ *Corresponding author: hunova@chmi.cz
}

\begin{abstract}
Ground-level ozone $\left(\mathrm{O}_{3}\right)$ is a key atmospheric constituent participating in many important atmospheric reactions, and has many negative effects both on human health and the environment. We have measured $\mathrm{O}_{3}$ ambient concentrations in four Czech rural areas of great natural value: the Orlické hory Mts., Novohradské hory Mts., České Švýcarsko and Jizerské hory Mts. For our measurement we used Ogawa diffusive samplers. The measurements were carried out during the vegetations seasons of 2004-2010, the samplers were exposed for two-weeks periods and the filters analyzed in the CHMl laboratory. The aim of this paper is to summarize the experience we have of using the diffusive sampling method in the field.
\end{abstract}

Keywords: ground-level ozone, diffusive samplers, exposure

\section{Introduction}

Ground-level ozone $\left(\mathrm{O}_{3}\right)$ is a key component of the atmosphere. As a potent oxidant and a source of the $\mathrm{OH}$ radical, it plays an important role in atmospheric chemistry, removing many air pollutants from the atmosphere by oxidation reactions (Seinfeltd and Pandis 1998). Moreover, due to its radiation-absorbtion properties, $\mathrm{O}_{3}$ is a potent green-house gas, contributing substantially to climate change (IPCC 2007). At high concentrations, $\mathrm{O}_{3}$ has negative effects both on human health, ecosystems and the environment (Royal Society 2008). For forests, it is still considered to be the most important air pollutant (Paoletti et al. 2010)

Ozone is a criteria pollutant and there are legal limit values for human health, vegetation and ecosystem protection (Hůnová 2003), and regular monitoring of concentrations of ambient $\mathrm{O}_{3}$ is therefore required. In Europe, the limit values for $\mathrm{O}_{3}$ are extensively exceeded (EEA 2016), and with regard to ambient air pollution, $\mathrm{O}_{3}$ is considered, together with aerosol, as the major threat.

In the Czech Republic $\mathrm{O}_{3}$ measurements started in 1993, and currently there are ca 50 stations, in different environments (urban, rural, mountain), within the nation-wide monitoring network continuously measuring $\mathrm{O}_{3}$ (ČHMÚ 2016). The data are gathered as 1 -hour mean concentrations in a nation-wide database ISKO (Information System of Air Pollution) run by the Czech Hydrometeorological Institute (CHMI).

The results are published regularly in annual reports in a bilingual Czech/ English version (ČHMÚ 2016) free to download at http://portal.chmi.cz/files/portal/docs /uoco/isko/tab_roc/tab_roc_CZ.html, and there are papers on the effects on human health and ecosystems (Hůnová et al. 2003; Hůnová and Schreiberová 2012; Hůnová et al. 2013).
With respect to a nation-wide $\mathrm{O}_{3}$ analysis, the current monitoring network is suitable. However, if we need a finer spatial resolution, for example, at the scale of a mountain range, the current network is not sufficient. To get a more detailed insight into the spatial variability in concentrations of $\mathrm{O}_{3}$ we need additional measurements. Passive or diffusive samplers, which provide such a complementary system, are used in many regions throughout the world (e.g. Grosjean et al. 1995; Helaleh et al. 2002; Sanz et al. 2007; Adon et al. 2010), and in particular are recommended for environmental studies (Krupa and Legge 2000). These low-cost devices do not need a power supply and are very easy to manipulate, which makes them very handy for use at locations that are difficult to access, such as mountain forests. Diffusive samplers might be useful for diverse tasks in atmospheric chemistry (WMO GAW 1997) and are widely used for determining the levels of both indoor and outdoor ambient air pollution. Nevertheless, there are still many uncertainties in application of diffusive samplers to be accounted for (Cox 2003). For example, in the field, it is necessary to be aware of the effect of environmental conditions (such as wind, air temperature and relative humidity) and what abrupt changes in these conditions may have on the performance of diffusive samplers (Vardoulakis et al. 2009).

To enlarge the existing nation-wide monitoring network we used diffusive samplers in four rural areas of a great natural value: the Orlické hory Mts., Novohradské hory Mts., České Švýcarsko and the Jizerské hory Mts. The measurements were made by students during the vegetations seasons in 2004-2010 as part of their diplo$\mathrm{ma}$ and Ph.D. theses. The aim of this paper is to summarize the experience we obtained using diffusive samplers, which might be useful for researchers using these measurements. 


\section{Methods}

\section{Diffusive samplers}

Diffusive samplers are devices for measuring concentrations of ambient air pollutants. As indicated by their name, the sampling procedure is based exclusively on the process of diffusion, in which the pollutant is transported to a filter impregnated with a suitable collecting medium by free flow, according to Fick's first law of diffusion (1).

$J_{1}=-D_{12} \times\left(d c_{1} / d z\right)$

where

$J_{1}$ is the diffusion flux of gas $\left[\mathrm{mol} \mathrm{cm} \mathrm{cm}^{-2} \mathrm{~s}^{-1}\right.$,

$D_{12}$ is the diffusion coefficient of gas 1 in gas $2\left[\mathrm{~cm}^{2} \mathrm{~s}^{-1}\right]$,

$c_{1}$ is the concentration of gas 1 in gas $2\left[\mathrm{~mol} \mathrm{~cm}^{-3}\right]$,

$z$ is the length of diffusion $[\mathrm{cm}]$.

A diffusive sampler is defined by the European Committee for Standardization as "a device capable of taking samples of gases or vapours from the atmosphere at a rate controlled by a physical process such as gaseous diffusion through a static air layer or a porous material and/ or permeation through a membrane, but which does not involve an active movement of air through the device". This is determined by the difference between the pollutant ambient concentration and the concentration at the sorbent, which should be negligible compared to the ambient level.

Diffusive samplers provide time-integrated values for periods ranging from days to several weeks.

The diffusive samplers are simple, inexpensive, and do not require an electricity supply. The major disadvantages are: (1) they do not provide continuous values, (2) and are sensitive to meteorological conditions. Careful design of the sampler, however, can substantially reduce the uncertainty (Hofschreuder et al. 1999).

Currently, diverse commercial diffusive samplers are available. Gerboles et al. (2006) in their laboratory and field comparison of measurements obtained using all the available diffusive samplers for ozone (Ogawa, Analyst, Radiello, IVL badge, Palmes tubes, Passam tubes, Passam badge) found that most of the samplers are suitable for measurements over period of a week and meet the requirement of $30 \%$ accuracy required by European legislation (EC 2002).

\section{Diffusive sampler Ogawa}

For our measurements, we used the commercial Ogawa sampler (Ogawa and Co., Pompano Beach Florida), which is widely and successfully used for measuring $\mathrm{O}_{3}$ in U.S. National Parks (e.g. Manning et al. 1996; Cooper and Peterson 2000). Koutrakis et al. (1993), who validated the Ogawa sampler, report that a relative humidity ranging from 10 to $80 \%$ and temperature ranging from 0 to $40^{\circ} \mathrm{C}$ do not influence the performance of the sampler at typical $\mathrm{O}_{3}$ levels (40-100 ppb). Fig. 1 shows the Ogawa

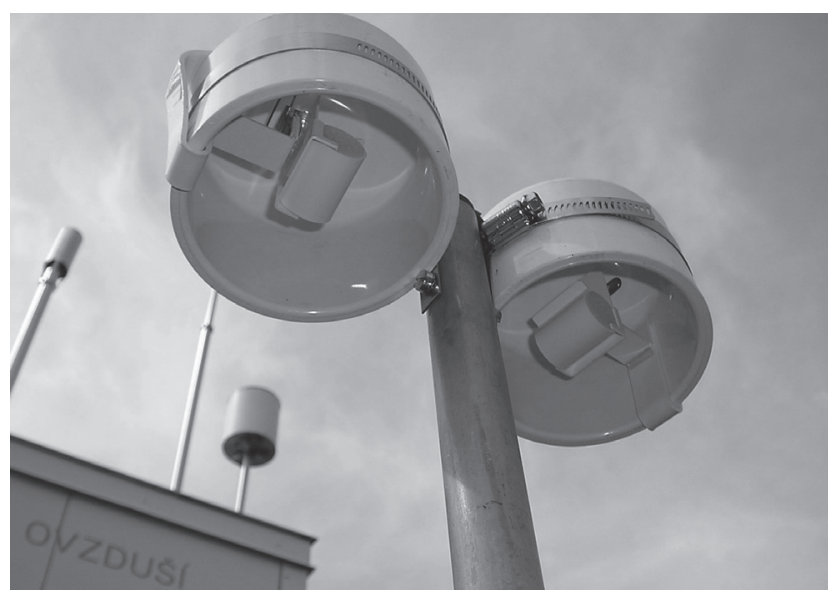

Fig. 1 Diffusive sampler Ogawa.

badge sampler in a shelter provided by the manufacturer, which protects it from unfavourable meteorological conditions.

The measuring technique was described in detail by Koutrakis et al. (1993). The principle is based on oxidation of nitrite ions on the filter to nitrate by ambient $\mathrm{O}_{3}$, and analysis of nitrate by ion chromatography. The amount of nitrate ion is proportional to the concentration of ambient $\mathrm{O}_{3}$. The filters coated with a nitrite-based solution were supplied by the manufacturer. The samplers were prepared and the exposed filters were analyzed for nitrate by ion chromatography in the CHMI laboratory in Ostrava. All laboratory procedures were done according to the Protocol for ozone measurement by Ogawa passive badges (Ogawa Company 2001). The time-weighted average $\mathrm{O}_{3}$ concentrations for two-week measurements were calculated based on the collected amount of nitrate on the filter, the uptake rate of the sampler and the exposure time. For each campaign, mean nitrate concentration obtained from field blanks was subtracted from the exposed filter values in order to determine the net nitrate concentration. The calculation of the $\mathrm{O}_{3}$ concentrations in our case, however, in contrast to the Ogawa Protocol (Ogawa Company 2001), was based on the empirical uptake rate obtained from the collocated measurements using a real-time analyser (Thermo Environmental Instruments TEI, M49), based on UV-absorbance as required in the EU (EC 2008). Detailed description of our approach is presented in Hůnová (2006).

\section{Study areas and organizational aspects of monitoring}

Ground-level ozone measurements were carried out by students, within their diploma and Ph.D. theses, in the Orlické hory Mts. (Šikýřová 2005), Novohradské hory Mts. (Běláková 2004; Matoušková 2005), České Švýcarsko (Habermann 2006; Holečková 2006) and Jizerské hory Mts. (Matoušková 2011), (Table 1, Fig. 2).

The samplers were placed $c a 2 \mathrm{~m}$ above ground level in forest clearings, at a reasonable distance from vegetation (trees and bushes) in order to avoid the $\mathrm{O}_{3}$ concentration reduction due to deposition and uptake by vegetation. 
Table 1 Areas studied.

\begin{tabular}{|l|l|l|l|l|}
\hline & \multicolumn{3}{|c|}{ Areas } \\
\hline & Orlické hory Mts. & Novohradské hory Mts. & České Švýcarsko & Jizerské hory Mts. \\
\hline Level of wildlife protection & Protected Landscape Area & Natural Park & National Park & Protected Landscape Area \\
\hline Altitude [m a.s.l.] & $940-1011$ & $770-1032$ & $210-420$ & $760-1100$ \\
\hline Measurement period & $\begin{array}{l}2004,2005 \text { vegetation } \\
\text { season }\end{array}$ & $\begin{array}{l}2004,2005 \text { vegetation } \\
\text { season }\end{array}$ & $\begin{array}{l}2004,2005 \text { vegetation } \\
\text { season }\end{array}$ & $\begin{array}{l}\text { 2006-2010 vegetation } \\
\text { season }\end{array}$ \\
\hline References & Šikýřová (2005) & Matoušková (2005) & $\begin{array}{l}\text { Habermann (2006), } \\
\text { Holečková (2006) }\end{array}$ & $\begin{array}{l}\text { Matoušková (2011), } \\
\text { Hůnová et al. (2011, 2016) }\end{array}$ \\
\hline
\end{tabular}

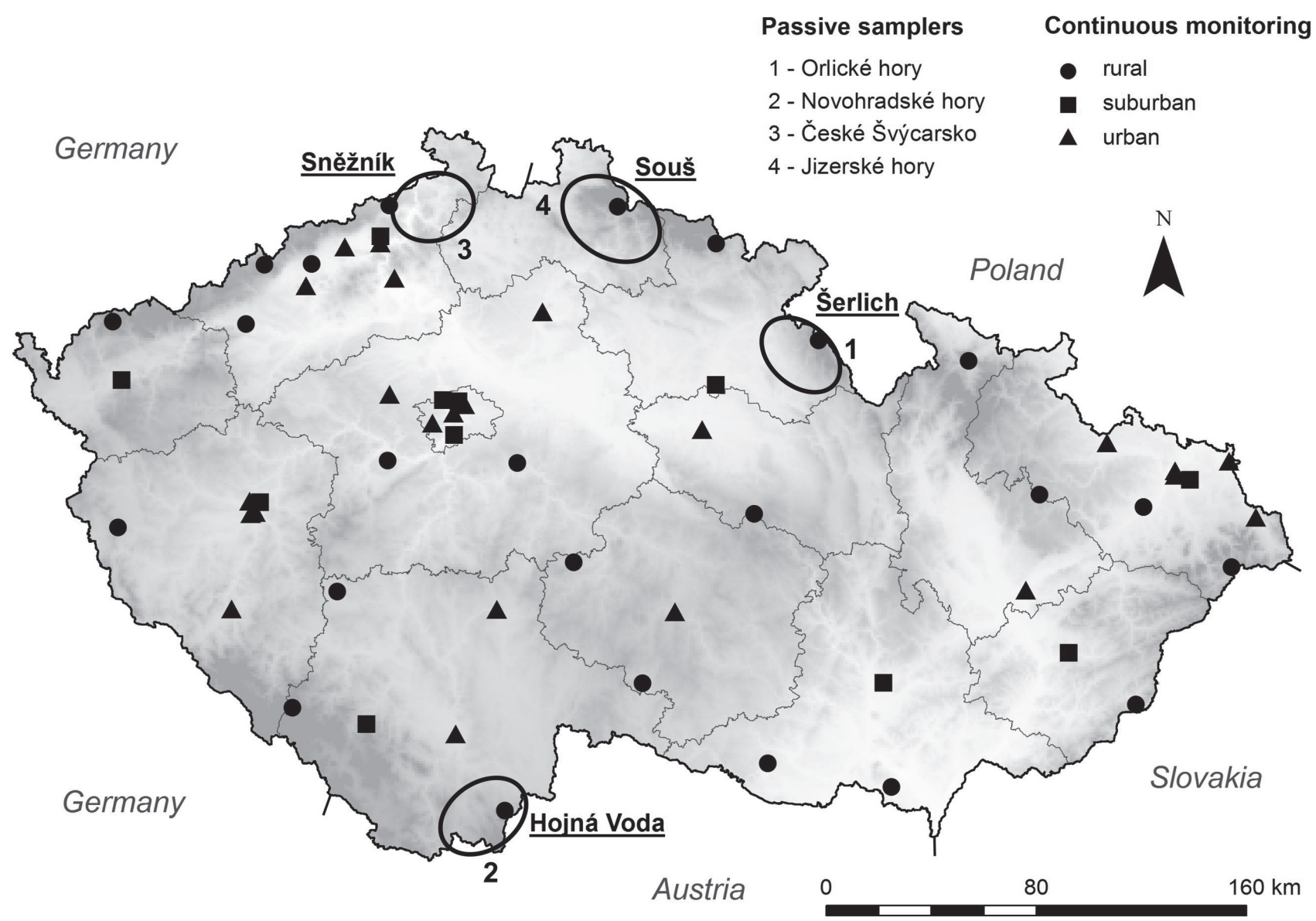

Fig. 2 Ground-level ozone monitoring. The sites at which there was continuous monitoring run by CHMI are depicted by point marks, areas with diffusive samplers are encircled. The underlined sites were used for collocated sampling.

We used a two-week exposures during the vegetation seasons. The first exposure of samplers was highly dependent on the meteorological conditions, as snow cover at the measuring sites prevented access to these areas.

\section{Results and Discussion}

\section{Overall functioning of the 0 gawa sampler Meteorological shelter}

The Ogawa sampler performed very well, it was simple to use and very convenient for measuring in mountain areas. The sampler itself was protected by a white shelter, specifically designed and provided by the producer. The purpose of this shelter is to protect the sampler from direct sunshine, which might affect $\mathrm{O}_{3}$ formation, and from wind and rain. Generally, the shelter provided sufficient protection, though during heavy rain accompanied by strong wind, the filters became wet. In such cases, the filter could not perform as expected and the reaction resulting in the oxidation of $\mathrm{NO}_{2}^{-}$to $\mathrm{NO}_{3}^{-}$was disrupted. Nevertheless, such events rarely occurred. The protective shelter was made of white propylene to reflect solar radiation. The white colour, however, made them very visible in the field and we lost several shelters due to vandalism.

\section{Empirical uptake rate}

To estimate the correct uptake rate is critical for obtaining reliable ambient concentrations of $\mathrm{O}_{3}$. Diffusion driving forces depend on the concentration gradient be- 
tween the trapped pollutant and its ambient concentration (e.g. Namiesnik et al. 2005). Fick's law holds, however, under ideal, steady state conditions assuming that the sorbent functions as a perfect sink. Nevertheless, in real sampling there are deviations from ideal conditions and thus the theoretical uptake rate can differ from actual rate (Yu et al. 2008). Moreover, Koutrakis et al. (1993), who validated the Ogawa sampler, explicitly declare that its function is not influenced by temperatures between 0 to $40{ }^{\circ} \mathrm{C}$, and relative humidity between 10 and $80 \%$. While the temperature range was met in the field in the areas studied, the relative humidity frequently exceeded $80 \%$.

In contrast to some other studies (e.g. Gerboles et al. 2006; Gibson et al. 2009), the theoretical uptake rate of $21.8 \mathrm{~cm}^{3} \mathrm{~min}^{-1}$ stated by the producer (Ogawa Company 2001) did not prove realistic in this study. Therefore, we developed an empirical uptake rate based on collocated measurements of diffusive samplers and continuous monitoring, similar to Bytnerowicz et al. (2008). The $\mathrm{O}_{3}$ levels, calculated using the theoretical or empirical uptake rate, differed by a factor of 2.3-3.9. This resulted in substantial underestimates of the concentration of $\mathrm{O}_{3}$ by a factor of 2-4 if the theoretical uptake was used. We assume that in the field, the laboratory uptake rate declared by the manufacturer is not applicable. Namiesnik et al. (2005) in their thorough review of the use of passive samplers in environmental analyses indicated the possible effects of environmental conditions on analyte uptake as the most difficult problem to cope with. Nevertheless, the authors who used Ogawa badge samplers in their studies mostly reported that they used the uptake rate declared by the manufacturer and did not expanded on the issue. The only exceptions are the papers presenting results from the U.S. (e.g. Bytnerowicz et al. 2008). Recently, Malmquist et al. (2014) reported an uptake rate of 27.3 $\mathrm{cm}^{3} \mathrm{~min}^{-1}$ for an Ogawa sampler in a Swedish urban environment. We can reasonably assume, however, that in mountain conditions the uptake rate would differ much more from the theoretical uptake rate, as occurred in our mountain forest measurements.

\section{Precision and accuracy}

The precision of our measurements was very high $\left(R^{2}\right.$ equalled 0.98 ). We could reduce the number of parallel filters from four, used earlier, to two. The accuracy was somewhat worse ( $R^{2}$ equalled 0.82$)$ but still acceptable. Similar studies with Ogawa samplers report analogous precision and accuracy (Manning et al. 1996).

\section{Macrosetting}

Macrosetting of the measuring site is critical for obtaining spatially representative results, and so careful attention should be paid to the selection of relevant sites. When measuring $\mathrm{O}_{3}$ at several sites, it is necessary to consider the aspect of the mountain slope. We found that records from sites with northern aspects to be consistently and significantly lower compared to the sites at similar altitudes but with southern aspects (Hůnová et al. 2016). This fact should be kept in mind in particular when constructing the map of $\mathrm{O}_{3}$ concentrations based on point measurements. To get comparable results, the measuring sites should have the same aspect.

Regarding the macrosetting of measuring devices, it is extremely important to place them at a sufficient distance from vegetation. Our results from the Jizerské hory Mts. clearly indicated that measuring at the forest edge consistently gave significantly lower $\mathrm{O}_{3}$ concentrations than that recorded at the same site but in a forest clearing at a distance of ca $20 \mathrm{~m}$ from the forest edge (Hůnová et al. 2016). This finding was foreseeable and is in agreement with other similar studies, such as e.g. Karlsson et al. (2006).

\section{Conclusions}

The diffusive samplers Ogawa proved to be a very good device for environmental studies in rural areas with a complex terrain during vegetation seasons. They are light to carry, easy to operate and do not need a power supply. They can be used very effectively for indicative measurements in complex terrain of mountain forests, to study both the spatial and temporal variability.

Based on our results, we cannot, however, recommend the use of the theoretical uptake rate stated by the producer for measurements in the field. Rather we would recommend the use of the empirical uptake rate obtained from the collocated measurement of a diffusive sampler and a continuous analyser located in the same area. This empirical uptake rate reflects field conditions of changing meteorological variables much better than a constant uptake rate derived under laboratory conditions. The commercially provided meteorological shelter for protection of exposed filters against extreme meteorological phenomena (such as direct sunshine, heavy rain, strong wind) proved effective under usual conditions. In exceptional weather, such as heavy rain accompanied by strong wind, it failed, however, to provide the required protection, and subsequently the filters became wet and did not perform satisfactorily.

\section{REFERENCES}

Adon M, Galy-Lacaux C, Yoboue V, Delon C, Lacaux JP et al. (2010) Long-term measurements of sulfur dioxide, nitrogen dioxide, ammonia, nitric acid and ozone in Africa using passive samplers. Atmos Chem Phys 10: 7467-7487.

Běláková Š (2004) Měření $\mathrm{O}_{3}$ pasivními dozimetry v Novohradských horách. Diploma thesis. In Czech. Institute of Environmental Studies, Faculty of Science, Charles University, Prague.

Bytnerowicz A, Arbaugh M, Schilling S, Fraczek W, Alexander S (2008) Ozone distribution and phytotoxic potential in mixed conifer forests of the an Bernardino Mountains, southern California. Environ Pollut 155: 398-408. 
Cooper SM, Peterson DL (2000) Spatial distribution of tropospheric ozone in western Washington, USA. Environ Pollut 107: 339-347.

Cox RM (2003) The use of passive sampling to monitor forest exposure to $\mathrm{O}_{3}, \mathrm{NO}_{2}$ and $\mathrm{SO}_{2}$ : a review and some case studies. Environ Pollut 126: 301-311.

ČHMÚ (2016) Air Pollution in the Czech Republic in 2015. Czech/ English. CHMI, Prague.

EC (2002) Directive 2002/3/EC of the European Parliament and of the Council of 12 February 2002 relating to ozone in ambient air. OJEC 67: 14-30.

EC (2008) Directive 2008/50/EC of the European Parliament and of the Council of 21 May 2008 on ambient air quality and cleaner air for Europe. OJEC L 152.

EEA (2016) Air quality in Europe - 2016 report. European Environment Agency, Luxembourg.

Gerboles M, Buzica D, Amantini L, Lagler F (2006) Laboratory and field comparison of measurements obtained using the available diffusive samplers for ozone and nitrogen dioxide in ambient air. J Environ Monit 8: 112-119.

Gibson MD, Guernsey JR, Beauchamp S, Waugh D, Heal MR, Brook JR, Maher R, Gagnon GA, McPherson JP, Bryden B, Gould R, Terashima M (2009) Quantifying the spatial and Temporal Variation of Ground-Level Ozone in the rural Annapolis Valley, Nova Scotia, Canada using Nitrite-Impregnated Passive Samplers. J Air Waste Manag Assoc 59: 310-320.

Grosjean D, Williams II EL, Grosjean E (1995) Monitoring ambient ozone with network of passive samplers: A feasibility study. Environ Pollut 88: 267-273.

Habermann J (2006) Měrení koncentrací přízemního ozonu pasivní dosimetrií v Národním parku České Švýcarsko ve vegetačním období 2004. Diploma thesis. In Czech. Institute of Environmental Studies, Faculty of Science, Charles University, Prague.

Helaleh MIH, Ngudiwaluyo S, Korenaga T, Tanaka K (2002) Development of passive sampler technique for ozone monitoring. Estimation of indoor and outdoor ozone concentration. Talanta 58: 649-659.

Hofschreuder P, van der Meulen W, Heeres P, Slanina S (1999) The influence of geometry and draught shields on the performance of passive samplers. J Environ Monit 1: 143-147.

Holečková M (2006) Měření koncentrací př́izemního ozonu pasivními dosimetry Ogawa v NP České Švýcarsko. Diploma thesis. In Czech. Institute of Environmental Studies, Faculty of Science, Charles University, Prague.

Hůnová I (2003) Nové imisní limity pro ochranu vegetace a ekosystémů v české legislativě. Ochrana ovzduší 15: 4-8.

Hůnová I (2006) Pasivní dozimetry Ogawa pro měření koncentrací přízemního ozonu: zkušenosti s aplikací a výsledky měření ve vybraných horských lesích ve vegetačním období 2004-2005. Ochrana ovzduší 19: 8-15.

Hůnová I, Livorová H, Ostatnická J (2003) Potential Ambient Ozone Impact on Ecosystems in the Czech Republic as Indicated by Exposure Index AOT40. Ecol Indic 3: 35-47.

Hůnová I, Malý M, Řezáčová J, Braniš M (2013) Association between Ambient Ozone and Health Outcomes in Prague. Int Arch of Occup Environ Health 86: 89-97.

Hůnová I, Matoušková L, Srněnský R, Koželková K (2011) Ozone influence on native vegetation in the Jizerske hory Mts. of the Czech Republic: results based on ozone exposure and ozone-induced visible symptoms. Environ Monit Assess 183: 501-515.

Hůnová I, Schreiberová M (2012) Ambient ozone phytotoxic potential over the Czech forests as assessed by AOT40. IFOREST 5: $153-162$
Hůnová I, Stoklasová P, Schovánková J, Kulasová A (2016) Spatial and Temporal Trends of Ozone Distribution in the Jizerské hory Mountains of the Czech Republic. Environ Sci Pollut R 23: $377-387$.

IPCC (2007) Climate Change 2007. Synthesis report. IPCC Geneve. Karlsson PE, Hansson M, Hoglund HO, Pleijel H (2006) Ozone concentration gradients and wind conditions in Norway spruce (Picea abies) forests in Sweden. Atmos Environ 40: 1610-1618.

Koutrakis P, Wolfson JM, Bunyarovich A, Froelich SE, Koichiro H, Mulik JD (1993) Measurement of ambient ozone using a nitrate-coated filter. Anal chem 65: 209-214.

Krupa SV, Legge AH (2000) Passive sampling of ambient, gaseous air pollutants: an assessment from an ecological perspective. Environ Pollut 107: 31-45.

Malmqvist E, Olsson D, Hagenbjork-Gustafsson A, Forsberg B, Matisson B, Stroh E et al. (2014) Assessing ozone exposure for epidemiological studies in Malmo and Umea, Sweden. Atm Environ 94: 241-248.

Manning WJ, Krupa SV, Bergweiler CJ, Nelson KI (1996) Ambient ozone (O3) in Three Class I Wilderness Areas in the Northeastern USA: Measurements with Ogawa Passive Samplers. Environ Pollut 91: 399-403.

Matoušková L (2005) Měření koncentrací př́izemního ozonu pasivní dosimetrií v Novohradských horách na lokalitě Vysoká. Diploma thesis. In Czech. Institute of Environmental Studies, Faculty of Science, Charles University, Prague.

Matoušková L (2011) Surface ozone influence on native vegetation: results based on ozone visible symptoms and stomatal flux. Ph.D. thesis. Charles University, Prague.

Namiesnik J, Zabiegala B, Kot-wasik A, Partyka M, Wasik A (2005) Passive sampling and/or extraction techniques in environmental analysis: a review. Anal Bioanal Chem 381:279-301.

Ogawa Company (2001) Protocol for ozone measurement using the ozone passive sampler badge. http://ogawausa.com /wp-content/uploads/2014/04/proozone.pdf

Paoletti E, Schaub M, Matyssek R, Wieser G, Augustaitis A, Bastrup-Birk AM, Bytnerowicz A, Gunthardt-Goerg MS, MullerStarck G, Serengil Y (2010) Advances of air pollution science: From forest decline to multiple-stress effects on forest ecosystem services. Environ Pollut 158: 1986-1989.

Royal Society (2008) Ground-level ozone in the 21st century: future trends, impacts and policy implications. Royal Society, London.

Sanz MJ, Calatayud V, Sanchez-Peňa G (2007) Measures of ozone concentrations using passive sampling in forests of South Western Europe. Environ Pollut 145: 620-628.

Seinfeldt JH, Pandis SN (1998) Atmospheric chemistry and physics. John Wiley, New York.

Šikýřová A (2005) Měření koncentrací pasivními dozimetry v Orlických horách ve vegetačním období 2004. Diploma thesis. Institute of Environmental Studies, Faculty of Science, Charles University, Prague (in Czech).

Vardoulakis S, Lumbreras J, Solazzo E (2009) Comparative evaluation of nitrogen oxides and ozone passive diffusion tubes for exposure studies. Atmos Environ 43: 2509-2517.

WMO GAW (1997) Report on Passive samplers for atmospheric chemistry measurements and their role in GAW. No 122. http:// mce2.org/wmogurme/images/reports/wmo-passive.pdf

Yu CH, Morandi MT, Weisel CP (2008) Passive dosimeters for nitrogen dioxide in personal/indoor air sampling: A review. J Expo Sci Environ Epidemiol 18: 441-451. 